\title{
Determining firm characteristics and the level of voluntary corporate governance disclosures among Malaysian listed property companies
}

\author{
Shabana Talpur ${ }^{*}$, Mohd Lizam $^{1}$, and Nazia Keerio ${ }^{1}$ \\ ${ }^{1}$ Faculty of Technology Management and Business, UTHM, Batu Pahat, Johor, Malaysia
}

\begin{abstract}
This study examined the level of voluntary corporate governance disclosures and the influence of firm characteristics (i.e., firm size, firm age, and firm market listing) on the level of these disclosures among Malaysian property listed companies. The check-list to measure the voluntary corporate governance disclosures was adopted from Malaysian corporate governance index 2011 by Minority Shareholder Watchdog Group (MSWG). The voluntary corporate governance disclosure practices and firm specific characteristics were obtained from annual reports of property listed companies on Bursa Malaysia for the period of 2012 to 2015. The findings suggested an improving voluntary corporate governance reforms in Malaysia. However, the firm size was found as an inflicting factor in determining the level and quality of voluntary corporate governance disclosure practices. On the contrary, the results found were contradicting the hypothesis related to firm age and firm market listing, as no relation of voluntary corporate governance disclosures and firm age and firm market listing. The study has made an interesting contribution toward the disclosure and corporate governance by contributing in understanding the importance of quality disclosure and good governance practices.
\end{abstract}

\section{Introduction}

Foreign investment is deemed to be vital source of foreign currency inflow through stock market investment. As in the case of Thailand in 1997-1998 crises, that occurred due to high withdrawal of foreign investment as the investor lost their confidence in the country's stock market [1,2]. [3], contend that foreign investors face high level of risk due to the chances of expropriate of investment by insiders (managers and block-shareholders) of the company. The effective and efficient stock market, with high level of transparency through financial statements, boosts investors confident in making financial decisions [4](Jaffar, Jamaludin, Rahman, \& Riduan, 2007). Investors gain confidence when they have sufficient information about the company to make investment decision. According to IASB (2010), "the two primary qualitative characteristics of information in financial statements are relevance and faithful representation". Relevance and faithful representation are basic characteristics for improving quality. The information is considered relevant and faithfully represented when it helps an investor to make sound investment decisions [5]. The disclosures made in annual report are the main source of periodical information for shareholders. The key objective of disclosure is to update analysts and the investors about the amount, timing, and uncertainty of future cash flows [6,7]. Boards and management must maintain quality disclosures and transparency as they are essential for informed decision-making as mentioned in Malaysian Code of Corporate Governance.

The significance of quality disclosures and usefulness of accounting information is a major concern by many empirical studies. In previous studies, the attributes and characteristics of firm and stock market are analysed to get the factor which influences the quality of corporate disclosures. [8] Salter (1998), in their study about emerging stock markets and quality of corporate disclosures, explained deficiency in good disclosure is the reason to limit the quantity of company's stock on foreign and local investor's portfolio. A good disclosure, may be mandatory or voluntary, are communication of economic information, portraying company's financial position and performance throughout financial year [9,10]. [9], contended the adoption and implementation of high quality disclosure practices is important to invite foreign and national investors, which creates reserves for developing countries.

This study evaluated the voluntary disclosure practices of corporate governance, which were developed and motivated to adopt by regularity bodies in Malaysia after surviving the late 1990's financial crisis. Along with that, these reforms have also motivated on global level to moderate the financial problem among developing economies. Malaysian code of corporate governance was introduced in 2001 for implementing the 
good governance reforms among both public and private companies. However, eventually the code was implemented through Bursa Malaysia listing requirements for listed companies. The Bursa Malaysia listing requirements mandate each listing company to disclose their corporate governance practices in annual reports - under the label of corporate governance statement. Along with that, the regulatory bodies also encourage listed companies to disclose additional information beyond statutory requirement to enhance the level and quality of information in annual report. Many studies have evaluated the corporate governance practices of emerging countries including Malaysia. However, this study is distinguished from previous literature. Firstly, it focuses on voluntary corporate governance practices of property sector of Bursa Malaysia. Secondly, Malaysian listed companies have majority of highly concentrated ownership companies as most of the companies are family owned. Lastly, the panel data set is rarely used in disclosure studies to evaluate the changes in disclosure practices in recent years.

This study is divided into four parts. First, the detailed previous literature is reviewed in the subsequent section, followed by section about research methodology adopted in this research. In the next section, results and analysis are presented. Lastly, this study is duly concluded in the end.

\subsection{Types of disclosures in financial statements}

Previous studies have considered quality of disclosures as the presentation of minimum level of mandatory as well as voluntary disclosures made by the company in annual financial statements. The mandatory disclosures are the information which is compulsory to disclose according to the rules and regulations imposed by financial regulatory bodies. [11], in their study about the interaction of mandatory and voluntary disclosure, differentiate the usage of both disclosure according to the information needed. They argue that while mandatory disclosure provides the information on past performance of company, voluntary disclosure proposed the information which helps to forecast about future earning of company.

\subsubsection{Mandatory disclosures}

Mandatory disclosures are amount of information in company's financial statements required by the regulatory bodies of a country to disclose up to a set standard [10]. Even though, mandatory disclosures are regulated by the laws and enforcement bodies, but many disclosure laps are observed in previous studies. [10], assessed the status of mandatory disclosure level among Zimbabwean companies listed on Zimbabwe Stock Exchange (ZSE). By taking all the listed companies as a sample size, the study found only 76.4 (mean disclosure of companies) out of 214 mandatory items were disclosed. The mandatory items were collected from three regulatory resources of the country (i.e., the adopted IASs standards, the Companies Act, and the listing rules of the ZSE).

\subsubsection{Voluntary disclosures}

Voluntary disclosures are additional information provided by company, beyond the statutory and legal requirements by regulatory bodies, like MASB etc., to enhance the quality of information disclosed, sufficient for making decision and assessing risk factors of company's securities by the user of annual reports. The research related to voluntary disclosures is an important determined identified since 1970's [2] and recently there has been increased focus on voluntary disclosures. [12], contended that voluntary disclosures are the way to communicate the shareholders of the company about the transparency and highlight company's good value.

Many previous studies discussed the reasons of why company discloses information in form of voluntary disclosure. Voluntary disclosures are the information which is beyond mandatory requirements [13], helps reduces information asymmetry $[14,15]$, building investor trust [16] and reduce cost of equity [17]. Furthermore, information asymmetry creates a negative image about company's stock which ultimately resulted in increased in the cost of capital because investor cover the risk associated with investment. [18], in their study examined the linkage between voluntary disclosure and stock liquidity. They suggested that companies should pursue high quality of disclosure which will reduce the information asymmetry and leads towards enhancement in stock market liquidity.

\subsection{Corporate governance}

The emergence of term "Corporate Governance" can be new, but the issue addressed in the system is discussed by the pioneer of economics. The study identified that the separation of ownership and control in the corporation can lead toward the coincidence of conflicts of interest. This discussion about conflicts of interest continues and in the early 1930s, [19] in their publications called "The Modern Corporation and Private Property", illustrated that with the separation of ownership and management of company may push the manager to not act in the best interests of stockholders. Additionally, [20] further developed the idea and proposed the fully-fledged concept of agency theory conflict and suggested corporate governance as mechanism to monitor and control management activities to avoid agency problem in company. The research and discussion on corporate governance were only restricted to the United States and Britain from 1970 's to 1980 's. However, in the early 1990's the research begins to expand and cover the major economies in the world such as Germany, Japan and United Kingdom. In the recent years, the explosion of research regarding corporate governance has been observed across both developed and emerging markets in the world. The academicians with multidiscipline have 
recognized the importance of the corporate governance either they are from economics and finance or from law, management and accounting fields. In the new era of globalization, along with the academicians, interest in corporate governance has been growing rapidly among the corporate world [21].

Notwithstanding, an optimum governance structure for a specific country is difficult to estimate, but the performance and transparency showed by a firm may indicate the most suitable corporate governance structure adapted by it. As stated by [22], the way corporate governance controls the operations, it guarantees companies involvement in value added activities for investor which is reflected by high quality disclosure provided in financial statements. [23], also maintained the quality of disclosures as an indicator for optimum corporate governance mechanism. The author defines it as "a mechanism for accountability, emphasizing the need to raise reporting standards in order to ward-off the threat of regulation. Higher disclosure results in improved transparency, which is one of the most essential elements of healthy corporate governance practices". Thus, transparency achieved through quality voluntary disclosures, reflects efficient and optimum corporate governance practices are being followed by a company [24]. Therefore, the disclosures regarding corporate governance information have appealed the interest of researchers in last decade. Numerous CG indices have been developed previously, but generally originated on developed economies. However, much less work has been performed on developing and emerging countries [25]. Therefore, this study is aimed to identify the disclosure practices regarding corporate governance among emerging countries as Malaysia.

\subsection{Firm characteristics}

As mentioned before, the voluntary corporate governance disclosures and quality financial reporting influence in reducing agency conflicts. The agency cost bear by firm can be reduced by increasing the level of information disclosed by firm [20]. Different factors have been examined in previous studies which play an important role in enhancing the level of voluntary disclosure by firm. In this context, firm characteristics are also considered influencing [26, 27, 16]. Following these researches, this study has also examined the voluntary corporate governance disclosure in the context of three firm characteristics: firm size, firm age and firm's market listing.

Firm size: Large firms are more evident as compared to smaller firms, and their public interest is also more exposed [28]. Therefore, firm size is a key factor while predicting the type of association a firm maintains with inside and outside environment. It is generally assumed that the firm with larger size has more influence on their stakeholders. As [29] claimed that the size plays an important role in companies' corporate disclosures. Larger firms have higher agency costs, compelling management to disclose more information to ease agency conflicts. Thus, firm size is considered as an important feature towards good corporate governance disclosure practices $[25,30]$. It also improves the voluntary corporate governance disclosures [20]. In this context, firm size is considered as an essential variable while explaining the disclosure level by previous studies. Therefore, by following previous studies such as [31], this study also evaluated voluntary corporate governance disclosures based on company size.

H1: Firm size influences the level of voluntary corporate governance disclosure among property listed companies of Malaysia.

Firm age: The firm age can influence the level of voluntary disclosure because the age considered as the stage of growth and development of a firm. [10], argues that as younger firms have lack of attractive track record, along with the cost and complexities related to gathering information, can contribute toward the phenomenon that younger firms have less motivation to disclose additional information in their annual reports. On the contrary older firms have a reputation, brand name and sufficient capital which gave them advantage to disclose more information and become additionally compliant as compared to their counterparts. Therefore, the variable of firm age has been considered important by previous studies [32, 33] while determining the voluntary disclosure practices of firms. Thus, this paper examined the influence of firm age on the level of voluntary corporate governance disclosure among property listed companies of Malaysia.

$\mathrm{H} 2$ : Firm age influences the level of voluntary corporate governance disclosure among property listed companies of Malaysia.

Firm market listing: When the company is listed on Bursa Malaysia, they must follow all listing prerequisites; for example, to follow Bursa Malaysia listing requirements, to get successfully listed. Similar condition is also applied in the case of code of corporate governance. Listed companies on Bursa Malaysia are required to make a statement in their annual reports about the compliance of corporate governance principles, as per stated in the Code (Malaysian Code of Corporate Governance 2012). Therefore, companies listing status, for how many years a company has been listed, affect the level of voluntary corporate governance disclosures practices of listed companies. Thus, this study analysed the level of voluntary corporate governance disclosures based on the number of years the sampled companies have listed.

H3: Firm market listing influence the level of voluntary corporate governance disclosure among property listed companies of Malaysia

\section{Methodology and research design}

\subsection{Data Collection}

In this paper, we investigated the annual reports of 85 listed companies under property sector of Bursa Malaysia for the period of 2012 to 2015 . The voluntary corporate governance disclosure and firm characteristics 
data was collected through content analysis. All the annual reports were downloaded from Bursa Malaysia website and each company's website was also visited as per requirement. The voluntary corporate governance disclosure (VCGDS) checklist was adopted from Malaysian corporate governance index 2011 by Minority Shareholder Watchdog Group (MSWG), which evaluates all listed companies of Bursa Malaysia, against those criteria on yearly basis. The voluntary corporate governance disclosure score (VCGDS) is the score obtained by each company based on their compliances to each disclosure on the checklist.

\subsection{Variable measurement}

For examining the relationship between voluntary corporate governance disclosures and firm characteristics VCGDS has been calculated. The measurement of VCGDS and firm characteristics is discussed below:

\subsubsection{Voluntary corporate governance disclosures score}

The checklist consists of 71 observations related to corporate governance information. Each observation was scored 1 if the company is disclosing that information, otherwise it was scored 0 for non-disclosure. The maximum disclosure was 71 if a company discloses all the items on the checklist. So, the VCGDS was calculated as follows:

$$
V C G D S=\frac{T D}{M D}
$$

where

VCGDS = Voluntary corporate governance disclosure score;

TD $=$ Total Disclosures;

$\mathrm{MD}=$ Maximum Disclosures .

\subsubsection{Independent variable}

Firm size: A firm is considered as large if it owns a large number of assets. So, the variable firm size will be measured as natural log of total assets own by firm.

Firm age: Firm age is measured by the number of year passed a company has been founded.

Firm market listing: A firm market listing is measured as number of years a company has been listed on Bursa Malaysia.

\subsection{Research model}

For the second part, the study examined the relationship between voluntary corporate governance disclosure and firm characteristics for the sample period of 2012 to 2015. The following pooled least square regression model is used because of the panel data set: where,

VCGDS = voluntary corporate governance disclosure score for each sample firm;

FIRMSIZE $=$ Natural log of total asset of each firm;

FIRMAGE = Number of year a firm has been founded;

FIRMMARLIST $=$ Number of year a firm has been

listed on Bursa Malaysia;

$\beta 1$ to $\beta 3=$ constants; and $\varepsilon=$ error term;

$\mathrm{i}=\mathrm{N}$ firm, and $\mathrm{t}=\mathrm{T}$ time periods

\section{Results and discussion}

\subsection{Descriptive statistics}

The VCGDI consists of 71 voluntary disclosures which were derived from Minority Shareholder watchdog criteria for assessing corporate governance practices in Malaysia. As shown in Figure 5.1, the means voluntary corporate governance has improved in four years. The mean of disclosure in four years has shown improved disclosure practices among sampled companies from $19 \%$ in 2012 to $26 \%$ in 2015 (35\% improvement). The average disclosure score in four years was $22 \%$. The average score was reported below from other studies conducted in Malaysia, for example [32, 7, 34] and [26] reported $31.35 \%, 91.5 \%$ and $53.20 \%$, respectively. The results of average voluntary disclosures were higher than many disclosure studies, for example [35, 36] and [37] from Italy, Australia and China, respectively. However, the average voluntary disclosure was reported below as compared to studies in other emerging economies. Such as [38, 39] and [40] reports $46 \%$ in Mexico, $61 \%$ in South African and $40 \%$ in Venezuela, respectively.

Descriptive statistics of company size was measured by natural $\log$ of company's total assets. The results show a range of $9.92(2.03 \mathrm{ml})$ to 16.33 (12.26 bn), with means size of $13.72(91.29 \mathrm{ml})$. The mean has evidenced an insignificant growth over the sampled period. Furthermore, Panel L presents the descriptive regarding company age, which range from 3 to 108 year during the sampled period, with mean age of 35.46 years among property listed companies in Malaysia. Lastly, the number of years the company has been listed on Bursa Malaysia is presented in Panel M. The descriptive reports a range of 0 to 54 years the companies have been listed, with the mean number of listing years was 21 years. It indicates that sample companies have included newly listed to very older listed companies.

\subsection{Panel data regression analysis}

As shown in Table 2, the results suggest a positive and significant coefficient of firm size. However, the results were insignificant of firm age and market listing. The result was consistent with previous studies, likewise [41, $39,25]$ and [42]. These studies also found a positive impact of company's size on voluntary disclosures. [43], also contended that large size companies have higher voluntary disclosure level as they have more agency problems due to their complex capital structure. 
Table 1. Descriptive statistics of voluntary corporate governance disclosure and explanatory variables.

\begin{tabular}{|c|c|c|c|c|c|}
\hline Variables & All & 2012 & 2013 & 2014 & 2015 \\
\hline $\begin{array}{c}\text { Panel A: } \\
\text { COMZIE }\end{array}$ & & & & & \\
\hline Mean & 13.7 & 13.67 & 13.73 & 13.67 & 13.8 \\
\hline Min & 9.9 & 9.9 & 9.9 & 10.4 & 10.52 \\
\hline Max & 16.3 & 16.3 & 16.33 & 15.66 & 15.82 \\
\hline STD & 14.3 & 14.33 & 14.34 & 14.04 & 14.19 \\
\hline $\begin{array}{c}\text { Panel A: } \\
\text { CMM }\end{array}$ & 12.8 & 12.83 & 12.85 & 12.85 & 12.85 \\
\hline Mean & 35.4 & 33.94 & 34.93 & 35.92 & 36.98 \\
\hline Min & 3.0 & 3.0 & 4.0 & 5.0 & 6.0 \\
\hline Max & 108 & 105 & 106 & 107 & 108 \\
\hline STD & 17 & 17.13 & 17.15 & 17.17 & 17.18 \\
\hline Panel A: \\
COMAGE
\end{tabular}

Table 2. Voluntary corporate governance disclosure Panel data regression analysis summary.

\begin{tabular}{|c|c|c|c|c|}
\hline Variable & $\begin{array}{c}\text { Co- } \\
\text { EFF }\end{array}$ & STD & T-Statis & Prob \\
\hline $\begin{array}{c}\text { COMSIZ } \\
\text { E }\end{array}$ & 0.008 & 0.035 & 0.2465 & 0.805 \\
\hline $\begin{array}{c}\text { COMM } \\
\text { ARLIST }\end{array}$ & -0.011 & 0.035 & -0.312 & 0.754 \\
\hline $\begin{array}{c}\text { COMAG } \\
\text { E }\end{array}$ & $1.11 \mathrm{E}$ & $4.10 \mathrm{E}$ & 2.7122 & 0.0070 \\
\hline C & -17.59 & 5.1523 & -3.4157 & 0.0007 \\
\hline $\begin{array}{c}\text { R- } \\
\text { squared }\end{array}$ & 0.822 & $\begin{array}{c}\text { F- } \\
\text { statistic }\end{array}$ & 7.10947 & \\
\hline $\begin{array}{c}\text { Adjusted } \\
\text { R- } \\
\text { squared }\end{array}$ & 0.790 & $\begin{array}{c}\text { Prob (F- } \\
\text { statistic }\end{array}$ & 0.000 & \\
\hline
\end{tabular}

As far as firm age is concern, the findings are again consistent with [44], which also found no significant relationship between voluntary disclosures and company age. However, some studies, for example Adrian [45], found positive relationship between voluntary corporate governance disclosures and company's age. However, these results were inconsistent with previous studies, for example $[9,46]$ which found a positive and significant relationship between voluntary disclosures and company market listing.

\section{Conclusion}

The relationship between voluntary corporate governance disclosures and corporate governance mechanism has been assessed by many studies in the last decade. However, rare studies investigated the impact of firm characteristic's influence on level of voluntary corporate governance disclosures. This study has contributed in the vast literature regarding disclosures and corporate governance by empirical results.

The study found that the voluntary corporate governance disclosure practices among Malaysian property listed companies have been improved by significant percentage. It was interesting to found that, although the checklist consists of voluntary disclosures, which are not required by regularity bodies. But the property listed companies are motivated to disclose this information for the benefit and interest of shareholders. On the other hand, the larger the company, the higher the disclosure level was found in this study, which evidence that large size companies have more interest in disclosing additional information as compared to small size companies.

The study made an exempt to provide overview of the voluntary corporate governance disclosure practices of Malaysian property listed companies; however more detailed study can be done for all the listed companies on Bursa Malaysia.

The authors would like to thank Universiti Tun Hussein Onn Malaysia (UTHM) for supporting this research under Postgraduate Research Grant Vote No. U615.

\section{References}

1. A. Bin-Zulkafli, M. Adul Samad, \& M. Ismail, Corporate Governance in Malaysia. Malaysian Institute of Corporate Governance. 1, 18 (1999)

2. S. S. Ho, \& K. S. Wong, J. Int. Account. Audit Taxat., 10(2), 139-156 (2001)

3. K. Cremers, \& V. B. Nair, J. Finance, 60(6), 28592894 (2005)

4. R. Jaffar, S. Jamaludin, C. A. Rahman, \& M. Riduan, Malaysian Accounting Review 6(2) (2007) (2007)

5. F. Van Beest, G. Braam, \& S. Boelens, Nijmegen Center for Economics (NiCE). Working Paper, 09108 (2009)

6. J. Banghøj, \& T. Plenborg, Account. Finance, 48(2), 159-180 (2008) 
7. L. L. Eng, \& Y. T. Mak. J. Account Publ. Pol., 22(4), 325-345 (2003)

8. S. B. Salter, Int. J. Account, 33(2), 211-234 (1998)

9. M. Al-Akra, I. A. Eddie, \& M. J Ali, BAR, 42(3), 170-186 (2010)

10. S. Owusu-Ansah, Int. J. Account, 33(5), 605-631 (1998)

11. E. Einhorn, J. Account. Res., 43(4), 593-621 (2005)

12. A. Alhazaimeh, R. Palaniappan,\& M. Almsafir,. Procedia Soc. Behav. Sci, 129, 341-348 (2014)

13. Y. Lan, L. Wang, \& X. Zhang, China J. Account. Res., 6(4), 265-285 (2013)

14. Cheng, \& Lo. J. Account Res., 44(5), 815-848 (2006)

15. O. Kim, \& R. E Verrecchia, J. Account. Econ., 17(1-2), 41-67 (1994)

16. D. G Barako, Afr. J. Bus. Manag, 1(5) (2007)

17. J. Piotroski,. Unpublished manuscript, University of Chicago (1999)

18. C. Leuz, \& R. E. Verrecchia, J. Account. Res., 38, 91-124 (2000)

19. A. A. Berle, \& Gardiner, C. Means. 1932. The modern corporation and private property, 204-205 (1968)

20. M. C. Jensen, \& W. H. Meckling, J. Financ. Econ., 3(4), 305-360 (1976)

21. L. A. Bebchuk, \& M. S. Weisbach, Rev. Financ Stud., 23(3), 939-961 (2010)

22. A. Shleifer, \& R. W. Vishny, J. Finance, 52(2), 737783 (1997)

23. A. Cadbury, Cadbury report: Tech reprt, HMG, London (1992)

24. H. Li, \& A. Qi, Corpor. Owner. Control, 5(2), 360366 (2008)

25. K. Samaha, K. Dahawy, K. Hussainey, \& P. Stapleton, Adv Account, 28(1), 168-178 (2012)

26. M. Akhtaruddin, M. A. Hossain, M. Hossain, \& L. Yao, JAMAR, 7(1), 1-19 (2009)
27. K. Aljifri, Adv Account, 24(1), 93-100 (2008)

28. Z. Watts, Positive accounting theory. Edgewood Cliff, NJ (1986)

29. S. J. Bhayani, S. East Asian J. Manag, 17(4), 6 (2010)

30. Y. B. Tariq, \& Z. Abbas, Econ Model, 35, 565-575 (2013)

31. R. Bauer, B. Frijns, R. Otten, \& A. Tourani-Rad, Pac. Basin. Finance J., 16(3), 236-251 (2008)

32. M. Akhtaruddin, \& H. Haron. ARA, 18(1), 68-82 (2010)

33. M. Hossain, \& M. Reaz, Corp. Soc. Resp. Env. Manag., 14(5), 274-288 (2007)

34. R. M. Haniffa, \& T. E. Cooke, Abacus, 38(3), $317-$ 349 (2002)

35. S. Lim, Z. Matolcsy, \& D. Chow, Eur. Account Rev., 16(3), 555-583 (2007)

36. L. Patelli, \& A. Prencipe, Eur Account Rev, 16(1), 5-33 (2007)

37. T. Vo, Brooklyn Law Review, 76, 2011-2006 (2010)

38. R. Price, F. J. Román, \& B. Rountree, J. Financ. Econ., 99(1), 76-96 (2011)

39. K. Jallow, C. G. Ntim, K. K. Opong, J. Danbolt, \& D. A. Thomas, J. Appl. Account Res., 13(2), 122144 (2012)

40. U. Garay, \& M. González, Corp. Govern. Int. Rev., 16(3), 194-209 (2008)

41. H. Elzahar, \& K. Hussainey, J. Risk Finance, 13(2), 133-147 (2012)

42. M. Allegrini, \& G. Greco, J. Manag. Govern, 17(1), 187-216 (2013)

43. K. H. Chung, \& H. Zhang, J. Financ. Quant. Anal., 46(01), 247-273 (2011)

44. N. H. Wan Abd Rahman, M. Mohamed Zain, \& N. H. Y. Yahaya Al-Haj, Soc. Respon. J., 7(2), 181201 (2011)

45. A. Cadbury, Long Range Planning, 32, 12-19 (1999)

46. A. Uyar, M. Kilic, \& N. Bayyurt, Intangible capital, 9(4), 1080-1112 (2013) 